printed material in Western languages bearing upon India, and the constantly expanding European manuscript collections of the Library, including the quasi-official muniments of former Viceroys of India, etc., which are valuable in supplementing the official records. Certain other departments of the Library also have material of importance for historical studies; for example, the Oriental manuscripts, especially the Persian, and the Oriental printed books. The study of Indian history in the British period has become very much more active since 1947, partly, so far as British scholarship is concerned, as a result of the expansion of university Oriental departments brought about by the implementation of the Scarbrough Commission Report of 1947 , partly as a result of the greatly stimulated interest of the newly independent Asian states in their own history and culture. The resources of the India Office Library are so preponderant that almost all modern Indian historical research pursued in the West is dependent upon them to a greater or lesser degree. ${ }^{5}$

The India Office Library may be used on application to the Librarian by any student or scholar from any country. Printed books are lent within the United Kingdom; manuscripts are lent, under certain conditions of security, to any university library or academy of learning anywhere in the world. Microfilms, photostats, and other photographic material can be supplied of any of the Library's resources.

5 The India Office Library and the School of Oriental and African Studies are co-operating in compiling a survey of all Western manuscripts bearing upon Southern Asian studies in the British Isles outside the India Office Library. The survey will eventually be published and is likely to prove of great value to Asian studies, especially historical studies, partly in showing what material exists upon particular topics and where it may be found, partly in indicating topics on which documentary material is available.

\title{
Sovetskoye Kitayevedenie [Soviet Sinology]
}

Contributed by Professor Derk Bodde, University of Pennsylvania

The appearance of the first number of the new journal, Sovetskoye Kitayevedenie [Soviet Sinology] (1958), one and a half years after the establishment of its parent organization, the Institute of Sinology (Institut Kitayevedeniya $)^{1}$ of the USSR Academy of Sciences, is further indication of the rapid growth of Soviet scholarly interest in China. ${ }^{2}$ The journal is attractively printed, uses an abundance of Chinese characters, and is similar in format to

1 I am greatly indebted to members of the Institute of Sinology for their cordial hospitality when I visited the Institute in Moscow on July 15, 1958, and for presenting me then with a copy of this journal. To my wife, Galia S. Bodde, I am likewise indebted for the linguistic assistance which made the writing of this notice possible.

2 The Institute was created late in 1956 by detaching and expanding what had been the Chinese Department of the Institute of Oriental Studies, Academy of Sciences, in Moscow. See translation of the Russian announcement by Ivar Spector in JAS, XVI (1957), $677-678$, and Rodger Swearingen, "Asian Studies in the Soviet Union," IAS, XVII (1958), 524-525. the Journal of Asian Studies, save that its pages have slightly narrower margins and this first issue contains more pages. Though it was originally planned to begin the journal in 1957 and thereafter publish six issues annually, ${ }^{3}$ this first number, consisting of 240 pages, appeared only in mid-r $95^{8}$ and seemingly says nothing about future frequency of publication.4

Non-Russian readers of Soviet Sinology will welcome the fact that its table of contents is printed not only in Russian, but also in Chinese, English, French, and German, and that brief summaries in Chinese and English (half a dozen lines or so each) appear at the end of each article. The following English summary

${ }^{3}$ See Spector, loc. cit.

4 A notice on its final page states that its materials were ready for typesetting on January 3, 1958, and were approved for final printing on May 26, 1958 . Hence Swearingen's statement (p. 536) that the first issue was published in January 1958 should be corrected. 
(p. 19) of the opening Editorial describes the general aims of the journal:

The editorial presents a short survey of the development of Soviet sinology in 1917-1957, and gives an account of the tasks of 'Sovietskoye Kitayevedenie' (Soviet Sinology). The main tasks of the magazine should be considered as follows: many-sided elucidation of achievements and experience of Socialist building in Chinese People's Republic; publication of scientific researches on problems of Chinese history, economy, literature, language and international relations; carrying on a constant struggle against bourgeois ideology and falsification in the field of sinology; holding creative discussions on the most important problems of sinology; active assistance in the development of brotherly friendship between the Soviet Union and Chinese People's Republic.

The journal's character can best be further indicated by reproducing its English table of contents (with, however, a few minor verbal changes made by myself purely for reasons of style or clarity):

Editorial: Greeting from Kuo Mo-jo. Articles and Communications: Soviet-Chinese Friendship-Factor for Peace and Universal Security; Soviet-Chinese Relations during the Early PostRevolutionary Years, by A. N. Kheifets; The Ideological Struggle among Chinese Intelligentsia during the Latter Part of 1918 and Early rgrg, by Y. M. Garoushyants; Achievements of Socialist Industrialization in China, by G. V. Astafyev; The Struggle for Socialist Ideology in China, by V. Y. Sidikhmenov; On Mao Tse-tung's Poetry, by L. Z. Eydlin; Concerning the Reformation of Chinese Writing, by G. P. Serdyoutchenko. Surveys and Notes: Economic Co-operation of the Soviet Union and the Chinese People's Republic, by P. I. Markov; Budget of the Chinese People's Republic, I9501957, by A. I. Chekhutov; Ch'ü Ch'iu-pai on Soviet Russia (1921-1922), by M. E. Shneider. Historical Documents: A Document of the $3^{\text {rd }}$ All-Russian Conference of Chinese Workers, by Y. M. Garoushyants; From the History of Soviet-Chinese Relations (1920-1921), by I. F. Kourdyukov; New Documents Concerning Ivan Petlin's Trip to China, by V. S. Myasnikov. Historiography and Bibliographical Critiques: The Socialist Revolution in China and Its Bourgeois Critics, by Y. A. Levada. Book Reviews. Sinology in the USSR: Survey of 1946-1956 Dissertations on Chinese History and Economics, by Y. M. Parfionovitch; The (Moscow) Institute of Sinology of the Academy of Sciences, USSR, by G. D. Soukhartchuk; The Institute of Oriental Languages of Moscow State University, by V. B. Gordeyev; The State Museum of Arts of Uzbekistan, by B. S. Sergeyev; Chronicle of Scholarly Activities; Books on China Published in the USSR in 1956. Sinology Abroad: The First, Second and Third Institutes of History of the Chinese Academy of Sciences; Sinology in Presentday Japan, by S. L. Tikhvinsky; Notes on the Congress of Junior Sinologues (at Marburg, 1957), by V. N. Nikiforov; In the Chinese People's Republic (Chronicle of Events).

Leaving aside the main articles in this journal, it is obvious that its many bibliographical and informational features alone make it of highest importance for anyone wanting to know what is being studied, published, and planned in Chinese studies in the Soviet Union today. Levada's article on bourgeois critics of China's socialist revolution (pp. 153-160), for example, is illuminating for its picture of the kind of Western European and American publications on modern China currently being read by Soviet scholars. ${ }^{5}$ The Book Review section (pp. 16I-197) gives critiques, both long and short, of fifteen publications: six of them in Russian, four in Chinese, two each in English and French, and one in German. ${ }^{6}$ The analysis by Parfionovitch (pp. 198-201) of 136 dissertations on China (and especially on Chinese history and economics) written by "candidates of sciences" at twenty-nine Soviet universities dur-

5 The article, which covers primarily the period of 1954-57, cites, among other works, such books as Belden's China Shakes the World, Fitzgerald's Revolution in China, Walker's China under Communism, Rostow's Prospects for Communist China, Juan-li Wu's Economic Survey of Communist China, and Ping-chia Kuo's China: New Age and New Oullook, as well as periodicals like the IAS, $P A$, New Republic, Time, Fortune, World Politics, Economist, Christian Science Monitor, Manchester Guardian, Le Monde, Gazette de Lausanne, and others.

6 Those in English are Solomon Adler, The Chinese Economy, and Allen S. Whiting, Soviet Policies in China, r917-1924. The French titles are Economie de la Chine socialiste, by Lavalé, Noiret, and Dominique, and the first issue of Revue bibliographique de la sinologie (actually, despite its title, published both in English and French). That in German is a linguistic study by Milan Romportl on the tones in Kuo-yii, published in Archiv Orientalni, XXI (Prague, I953), 276-352. 
ing $1946-56,{ }^{7}$ criticizes them rather trenchantly and offers recommendations for their improvement. ${ }^{8}$ In the brief account of the (Moscow) Institute of Sinology (pp. 20I-202), we are told about ten general fields of research which have been laid out for it in its first Five-year Plan, as well as several specific important research projects. $^{\theta}$ Likewise, the following account of the Institute of Oriental Languages at Moscow

7 These should not be confused with dissertations for the degree of Doctor of Sciences, i.e., Ph.D. They represent a lower level of accomplishment, usually based on three years of graduate study.

8 About 60 per cent of these 136 dissertations originated from institutions in Moscow and Leningrad; about 80 per cent were written during 1952-56 (showing the rapid rise of China interest during these years). Their classification according to disciplines is: history, 72; economics, 22; philosophy, 9; philology, 18; literature, 7; geography and law, 3 each; education and art, I each. Grouped by topics, most of them fall into one of three general categories: (I) foreign colonial expansion in China, (2) the Chinese people's struggle for national liberation, (3) China's economic development. Parfionovitch criticizes them on three main counts: (I) too many of the economic dissertations fail to make adequate analysis of their data; (2) there are too many duplications of topic among different dissertations (indicating insufficient co-ordination among the institutions concerned); (3) far too many deal only with the twentieth century, whereas earlier periods of China are neglected. In conclusion, he recommends that persons writing dissertations on China should be equipped to use original sources through a knowledge of the language, and that such dissertations should be confined to institutions having genuine competence on China.

9 The Institute has a staff of about 120 (including both research scholars and other personnel). Some 40 per cent of its energies will be devoted to research on China from IgIg to the present time. Other main fields of research may be summarized as struggle of the Chinese people against feudalism and colonialism prior to 1919 , development of slave and feudal relationships in China, history of social and political thought, study of languages and dialects, study of literature and other cultural achievements, translation of major Chinese written works, and study of the history of sinology in the USSR and abroad. Among the specific projects listed-some collaborative, others individual-are a large group work on aspects of Chinese history from I9I9 to I956; a long-term group project for the translation of Ssu-ma Ch'ien's Shih chi [Historical Records]; a study by N. T. Fedorenko, to appear shortly, on the Shih ching [Book of Songs]; a four-volume Great Chinese-Russian Dictionary, to include over 250,000 words and phrases; a large compendium of documents on Russo-Chinese relations (two collections to appear in 1958); and an updating to the present time of P. E. Skachkov's well-known Bibliografiya Kitaya [Bibliography on China], originally published in 1932 .
University (pp. 202-204) provides an outline of the curriculum there followed. ${ }^{10}$ And finally, under the title, "Books on China Published in the USSR in 1956 " (pp. 212-217), a listing of 164 publications (books, pamphlets, dissertations, etc.) is made under ten topical headings. ${ }^{11}$

Aside from specific points of interest that may emerge from the foregoing remarks, a perusal of this first issue of Soviet Sinology suggests to this writer two general conclusions: (I) What is termed "sinology" (literally, "Chinese studies") in the Soviet Union is overwhelmingly focused on recent, and especially contemporary, developments. In this respect, therefore, as well as in its choice of subjects within this rather restricted time span, it differs profoundly from "sinology" as traditionally thought of in Western Europe or even the United States (where, too, there is a relatively strong emphasis on modern China). (2) Soviet sinology exemplifies a situation found in much Soviet scholarship: the very close relationship between scholarship and politics and ideology. It will be interesting to see, as future issues of this important journal appear, whether these characteristics remain unchanged or will undergo modification with the passage of time..$^{12}$

10 I do not summarize this here, since an account is to be found in Swearingen, pp. 523-524.

11 These are the Chinese Communist Party, with 6; Chinese People's Republic, 3; socialist reforms and development of the national economy, 19; law, 13; literature and art, 5I; philology, 8; the Soviet Union and China, 20; philosophy and ideology, 3; history, 33; geography, 8 . The great majority of these publications are popular in nature, and a surprising number appear in languages of the USSR other than Russian. Many are translations of modern Chinese literature, while not a few are books for children. Dissertations (of the sort described above) also appear in fair numbers, and their extreme brevity (rarely more than twenty pages), as well as subject matter, lend weight to the strictures there made. In short, it seems unlikely that more than ten per cent of these I 64 publications, at most, can be considered as substantial works of scholarly importance.

12 For persons wishing to subscribe to Soviet Sinology or to communicate with its editors, it should be added that its address is Institute of Sinology, Room I52, Kitaiski Proyezd 7, Moscow, and that its editorial board consists of E. F. Kovalev (chief editor), G. V. Astafyev, L. I. Duman, N. I. Konrad, A. G. Krymov, A. A. Martynov, V. N. Nikiforov, I. M. Oshanin, A. S. Perevertaylo, N. T. Fedorenko, V. M. Shteyn, and M. F. Yuryev. 
Since the above was written, the second number (Sept. 1958) of Soviet Sinology has been received. A notice in it states that the journal will hereafter appear four times annually, each issue to consist of 240 pages, with 48 roubles as the annual subscription. The arrangement of materials in this second number is similar to that in the first. The following are some of its highlights:

[Contemporary China:] Contributions dealing with agricultural development (A. I. Stadnichenko); agriculture on Hainan (V. I. Iskoldsky); industrial, trade and financial management (A. I. Ivanov); trade with Japan (L. V. Kotov). [Modern China:] The RussoChinese treaty of 1896 (G. V. Efimov); Sun Yat-sen's T'ung-meng Hui (V. I. Danilov); Sinkiang-Soviet relations, 1918-2I (B. P. Gurevich); the March 192I agreement between the Far Eastern Republic and Northeast China (P. F. Zhuikov-Alexandrovsky). [Pre-modern and general:] The ancient poet $\mathrm{Ch}^{\prime} \ddot{\mathrm{u}}$ Yüan

\section{The Editor, The Journal of Asian Studies}

\section{Dear Sir:}

It is gratifying to have my little wennti about "reign titles" or "era names," published some years ago in that disputatious and ephemeral journal Wennti, taken so seriously by a firstrate historian of modern China that she has published, in effect, a lengthy gloss on the era name $t^{\prime} u n g$ chih, written in the true philological spirit. ${ }^{1}$ I can find no fault with Dr. Wright's commentary: it would make a grand footnote in the Pelliot tradition. She has, however, invited me (or some philologist) "to show how a philologist would have planned 'a reasonable amount of research' to discover the meaning

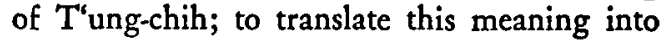
two English words; and to incorporate these words in a table of standard equivalents, ...." It would be impolite of me to reject this challenge.

1 Mary C. Wright, "What's in a Reign Name: The Uses of History and Philology," JAS, XVIII (Nov. r958), 103-106.
(N. T. Fedorenko); the Yuan dramatist Kuan Han-ch'ing (V. F. Sorokin); meaning of the word chin (silk embroidery) in ancient China (E. I. Lubo-Lesnichenko); Azerbaijan's contacts with China, 13th-15th centuries (B. S. Ashurbeili); mission of Seitkul Ablin from Tobolsk to China, I668-71 (A. M. Filippov); latinized orthography of Chinese compound verbs (T. P. Zadoyenko); Kuo Mo-jo's studies on ancient Chinese slavery (L. S. Vasiliev).

Book reviews cover fourteen publications, including two American (Schurmann's Economic Structure of the Yüan Dynasty and Wiens' China's March toward the Tropics). Numerous notices deal with matters of sinological interest within the USSR, such as the collections of books on China in several libraries; plays about China on the Soviet stage; the teaching of Chinese in a Moscow school; and a list of magazine articles on China published in the USSR in 1956. The section, "Sinology Abroad," contains a nine-page article on "Sinological Centers in the USA" (B. N. Zanegin).

\section{COMMUNICATIONS}

This philologist would, he thinks, have gone about the thing in much the same way that Dr. Wright did. Dr. Wright has certainly done a reasonable amount of work. She leaves unanswered, as I left them unanswered in Wennti, my questions: "How should we handle reignnames of the abbreviated-quotation type? e.g. ch'ui kunga," and "What is the grammatical structure of reign-names?" Certainly if we can show that $t^{\prime} u n g$ chih is of the abbreviated-quotation type, as Dr. Wright seems to have done, our opinion about the syntactical relation between the two constituents may be amended, e.g., we may abandon the notion that it is a simple attribute-head construction in favor of some other theory. In era names we may detect such constructions as unqualified noun (feng huang $\left.{ }^{b}\right)$, subject-predicate (? $t^{\prime}$ ien pao $0^{\circ}$ ), qualifier-substantive ( $t^{\prime}$ ien $p a o^{d}$ ), or verb-object (? $\left.k^{\prime} a i p a o^{a}\right) .^{2}$ Dr. Wright's researches have revealed that tung chih is probably a kind of

2 These terms from the syntax of Indo-European languages may be quite inappropriate. Consider them only as possible analyses. The question "what is the 